NOTE

\title{
Microsatellite marker development in the protozoan parasite Perkinsus olseni
}

\author{
Belén G. Pardo ${ }^{1, *}$, Asunción Cao ${ }^{2}$, Román Vilas ${ }^{1}$, Elvira Abollo ${ }^{3}$, Antonio Villalba ${ }^{2}$, \\ Paulino Martínez ${ }^{1}$
}

\author{
${ }^{1}$ Departamento de Genética, Facultad de Veterinaria, Universidad de Santiago de Compostela, Campus de Lugo, \\ 27002 Lugo, Spain \\ ${ }^{2}$ Centro de Investigacións Mariñas, Consellería do Mar da Xunta de Galicia, 36600 Vilanova de Arousa, Spain \\ ${ }^{3}$ Centro Tecnológico del Mar - Fundación CETMAR, Eduardo Cabello s/n, 36208 Bouzas-Vigo, Spain
}

\begin{abstract}
The analysis of an enriched partial genomic library and of public expressed sequence tag (EST) resources allowed the characterization of the first microsatellite loci in the protozoan parasite Perkinsus olseni. Clonal cultures from laboratory isolates derived from infected clams Ruditapes decussatus (from Spain), R. philippinarum (from Spain and Japan), and Austrovenus stutchburyi (from New Zealand) were used for the characterization of 12 microsatellites. Low variation was detected at most loci, with the number of alleles at polymorphic loci ranging from 2 to 7 (average $3.20 \pm 0.51$ ) and gene diversity from 0.11 to 0.79 (average $0.40 \pm 0.07$ ). Preliminary results show that (1) isolates of $P$. olseni are diploid cells, and (2) multiple infections can occur within a single host. Eight of the loci analyzed successfully cross-amplified in the congeneric species $P$. mediterraneus. These microsatellite markers will be useful to analyze in detail the population genetic structure of $P$. olseni, crucial for the efficient management of this parasitic disease.
\end{abstract}

KEY WORDS: Microsatellites $\cdot$ Perkinsus olseni $\cdot$ Genetic diversity $\cdot$ Clams $\cdot$ Diploidy $\cdot$ Protozoan · Parasite

Resale or republication not permitted without written consent of the publisher

Perkinsus olseni is a protozoan parasite with a genome size around 28 megabases $(\mathrm{Mb})$ organized in 9 chromosomes (Teles-Grilo et al. 2007) that has been blamed for high mortalities of venerid clams in Portugal, Spain, and Korea (Azevedo 1989, Santmartí et al. 1995, Park et al. 1999). The species was originally described parasitizing abalones Haliotis ruber, though its host range also includes several species of clams and oysters. This parasite has been reported in a broad geographic range, including Oceania (Australia and New Zealand), East Asia (Korea, Japan, China, and Thailand), South America (Uruguay), and Europe (Portugal, Spain, France, and Italy). The first occurrence of the parasite in Italy, Portugal, and Spain was reported in the 1980s. P. olseni most likely originated in the
Pacific Ocean and was introduced into Europe and South America through Manila clam Ruditapes philippinarum transfers (Hine 2001, Villalba et al. 2004).

Microsatellite loci have been characterized in few species of protozoan, mainly human parasites belonging to the genera Plasmodium (Karunaweera et al. 2007), Trypanosoma (Balmer et al. 2006), Leishmania (Rougeron et al. 2010), Sarcoystis (Asmundsson et al. 2006), Toxoplasma (Ajzenberg et al. 2002), and Cryptosporidium (Feng et al. 2000). These markers have proved to be useful in the genetic characterization of parasite populations, which has led to a more efficient management of the disease. For example, microsatellites of $P$. falciparum have been use to identify virulence genes, the detection of natural selection of 
phenotypes associated with resistance to drugs, and the demonstration of a variety of population genetic structures with important epidemiological implications (Su et al. 2007).

Here we report the isolation and characterization of microsatellite loci for the first time in Perkinsus olseni. Our goal was to develop a set of highly variable genetic markers for analyzing population structure and life cycle of this parasite in future work. For this, we followed 2 different approaches. First, a microsatellite-enriched genomic library from $P$. olseni was developed using the relatively quick and inexpensive FIASCO protocol (Zane et al. 2002). Total genomic DNA from $10^{7}$ cells of a culture derived from a highly infected clam Ruditapes decussatus was extracted using the DNAzol reagent ${ }^{\circledR}$ (Invitrogen Life Technologies ${ }^{\mathrm{TM}}$ ) according to the manufacturers' instructions, and 250 ng DNA were simultaneously digested with MseI and ligated to MseI amplified fragment length polymorphism (AFLP) adaptor. A single biotinylated probe containing an $(\mathrm{AC})_{17}$ repeat motif, coupled with magnetic bead separation technology, constituted the basis of the enrichment protocol. PCR products above $200 \mathrm{bp}$ were ligated into pGEM-T Easy Vector (Promega) and transformed into JM109 high efficiency competent cells (Promega) as described by Pardo et al. (2006). A total of 576 white transformant clones were picked and re-grown overnight into microtiter plates with $120 \mu$ l of freezing medium (final concentration: $36.0 \quad \mathrm{mM} \quad \mathrm{K}_{2} \mathrm{HPO}_{4}$, $13.2 \mathrm{mM} \mathrm{KH}_{2} \mathrm{PO}_{4}, 0.4 \mathrm{mM} \mathrm{MgSO}{ }_{4}, 1.7 \mathrm{mM} \mathrm{Na}_{3}$-citrate, $6.8 \mathrm{mM}\left(\mathrm{NH}_{4}\right)_{2} \mathrm{SO}_{4}, 4.4 \%$ [v/v] glycerol) plus ampicillin at $37^{\circ} \mathrm{C}$. Plasmids were purified using the DirectPrep 96 Miniprep kit (Qiagen) and sequenced following the ABI Prism BigDye ${ }^{\mathrm{TM}}$ Terminator v3.1 Cycle Sequencing Kit protocol in an ABI 3730xl sequencer (Applied Biosystems). In a second approach, we screened the GenBank EST resources of this species (98 sequences; Ascenso et al. 2009) to track microsatellites motifs. The microsatellite search was conducted using the program Sputnik (http://espressosoftware.com/sputnik/index.html). All sequences were clustered to avoid redundancy using CAP3 (http://seq.cs.iastate.edu/) with default parameters.
A total of 237 out of 429 good-quality sequences ( $>100$ bp; PHRED score $>20$ ) from the enriched library contained short tandem repeats, and 198 were unique. A total of 11 tandem repeat motifs were detected in 98 expressed sequence tag (EST) sequences from GenBank, which clustered in 4 unique sequences. PCR primers flanking microsatellites that contained $\geq 8$ repeats in dinucleotide and $\geq 4$ repeats in tri- and tetranucleotide motifs were designed using the online primer design software PRIMER3 (http://frodo.wi.mit. edu/primer3/primer3_code. html). Twenty-six primer pairs could be designed from the enriched library, and 8 of them successfully amplified the target regions. All primers designed within the 4 unique EST sequences correctly amplified the targets. The lack of amplification of some primer pairs from selected sequences is a common observation in these types of studies and has been related with the low quality of sequences and/or inappropriate primer design (Pardo et al. 2007). Annotation of the 12 loci was performed using BLASTX against NCBI 'nr' (nonredundant protein database) database, which searches proteins using a translated nucleotide query (http:// blast.ncbi.nlm.nih.gov/Blast. cgi?). Homology expectation (E)-values (see http:// www.ncbi.nlm.nih.gov/BLAST/tutorial/Attschul-1.html\# head2 for specific definition) $<10^{-5}$ were considered for gene annotation. Five of the 12 screened loci showed E-values $<10^{-5}$ (Table 1).

Polymorphism at each locus was determined in parasites isolated from a variety of hosts species obtained from different localities: carpet shell clams Ruditapes decussatus from Ría de Arousa, Ría de Pontevedra (both bays in Galicia, NW Spain) and Río Carreras (Huelva, SW Spain); Manila clams R. philippinarum from Delta de l'Ebre (Catalonia, NE Spain) and Japan, and clams Austrovenus stutchburyi from New Zealand. In vitro Perkinsus olseni cultures were established from the gills of one clam from each Iberian Peninsula site (Ría de Arousa, Ría de Pontevedra, Río Carreras, and Delta de l'Ebre) using the culture medium JL-ODRP-2A (Casas et al. 2002a). The PCR procedure described by Casas et al. (2002b) was used to confirm that the cultured cells corresponded to $P$. olseni by analysing ca. $5 \times 10^{6}$ cells from each culture.

Table 1. BLAST search information about microsatellite-containing sequences. $E$-value: expectation value

\begin{tabular}{|llll|}
\hline Locus & Accession no. hit & E-value & Information \\
\hline Pol-USC7 & EER19832.1 & $8 \times 10^{-6}$ & Hypothetical protein Pmar-PMAR006724 [Perkinsus marinus ATCC 50983] \\
Pol-USC8 & EER08584.1 & $2 \times 10^{-21}$ & Hypothetical protein Pmar-PMAR017637 [Perkinsus marinus ATCC 50983] \\
Pol-USC9 & EER16958.1 & $1 \times 10^{-15}$ & Serine/threonine-protein kinase rio1, putative [Perkinsus marinus ATCC 50983] \\
Pol-USC11 & BAG85335.1 & $9 \times 10^{-61}$ & Adhesion related protein[Perkinsus olseni] \\
Pol-USC12 & EER04606.1 & $6 \times 10^{-45}$ & Hexokinase-7, putative [Perkinsus marinus ATCC 50983] \\
\hline
\end{tabular}


The in vitro cultures were cloned by limiting dilution plating in 96-well culture plates, and 3 monoclonal derivatives of each isolate culture were expanded. Thus, 3 clonal cultures were produced per host from each location on the Iberian Peninsula, allowing investigation into whether infections with multiple strains of $P$. olseni could occur in one individual host. Additionally, 3 P. olseni clonal cultures derived from 3 different $R$. philippinarum clams from Japan and 3 clonal cultures deriving from $3 \mathrm{~A}$. stutchburyi clams from New Zealand were provided by C. F. Dungan (Maryland Department of Natural Resources, Cooperative Oxford Laboratory). This rendered a total of 18 clonal cultures in the study to estimate genetic diversity. DNA from $10^{7}$ cells of each clonal culture was isolated with DNeasy Blood \& Tissue kit (Qiagen). PCR was carried out in a total volume of $15 \mu \mathrm{l}$ containing approximately $30 \mathrm{ng}$ of DNA, $1 \mu \mathrm{M}$ of each primer (the forward was labelled), $0.1 \mathrm{mM}$ of dATP, dTTP, dCTP, dGTP, 1.5× PCR Gold Buffer, $1.5 \mathrm{mM} \mathrm{MgCl}$, and $0.5 \mathrm{U}$ of AmpliTaq Gold DNA polymerase (Applied Biosystems). PCR was performed in a PTC-200 thermal cycler (MJ Research) as follows: an initial denaturation at $95^{\circ} \mathrm{C}$ for $10 \mathrm{~min}$ followed by 35 cycles at $94^{\circ} \mathrm{C}$ for denaturation during $45 \mathrm{~s}, 50 \mathrm{~s}$ at the specific annealing temperature (Table 1), and $50 \mathrm{~s}$ at $72^{\circ} \mathrm{C}$ for extension. A final extension step was performed at $72^{\circ} \mathrm{C}$ for $10 \mathrm{~min}$. An initial assessment of microsatellite amplification efficiency and polymorphism was conducted in a subsample of 5 clonal cultures by doing the PCR with unlabelled primers and running the product on $2.5 \%$ agarose gels stained with ethidium bromide and visualized under UV light. Those microsatellites which produced bands of expected size were further analyzed on an $\mathrm{ABI}$ 3730xl automatic sequencer (Applied Biosystems), the forward primer of each pair being $5^{\prime}$ fluorescently labelled (Applied Biosystems) (detailed in Table 2). Genotyping was

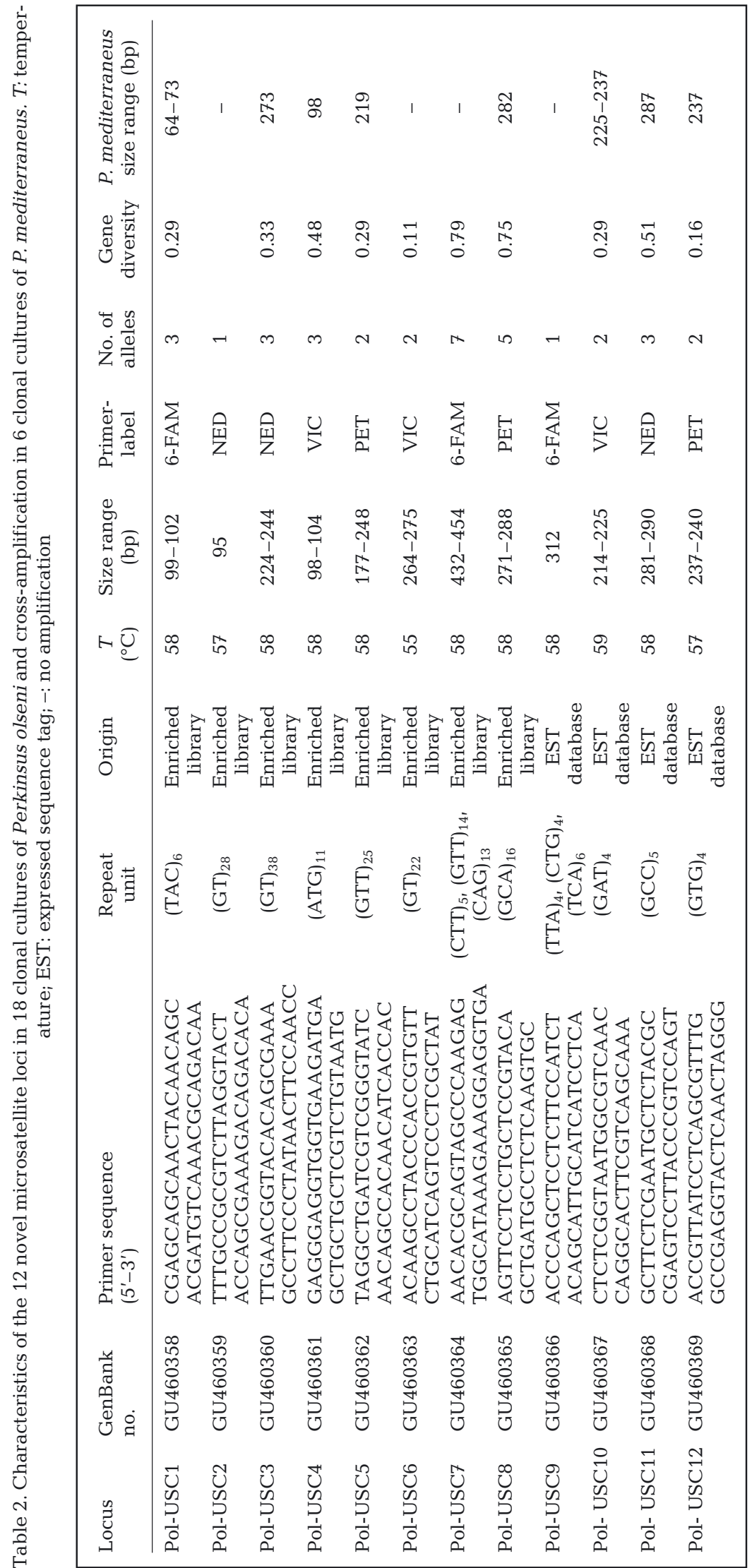


carried out using the GeneMapper 4.0 software (Applied Biosystems), with GenScan 500LIZ as the internal size standard. Non-amplification of these microsatellites was observed in non-infected hosts used as negative controls.

Estimates of genetic diversity (allele number and gene diversity; Nei 1987) were obtained with the program Genetix version 4.05 (Belkhir 2004) using the 18 clonal cultures (Table 2). Amplification was observed at all clonal cultures from the Iberian Peninsula but failed in 4 (Pol-USC2, Pol-USC4, Pol-USC6, and PolUSC7) and 1 (Pol-USC6) loci at the clonal cultures from Japan and New Zealand, respectively. Polymorphisms were observed among the samples analyzed for this study at 10 of the 12 microsatellite loci. Two loci were monomorphic for these samples, one locus derived from the enriched genomic library and the other one from the EST database. The number of alleles of polymorphic loci ranged from 2 at several microsatellites to 7 at Pol-USC7 (average $3.20 \pm 0.51$ ). Gene diversity ranged from 0.11 (Pol-USC6) to 0.79 (Pol-USC7) (average $0.40 \pm 0.07$ ). Private alleles were observed in clonal cultures from Japan (6) and New Zealand (7). The presence of heterozygotes at Perkinsus olseni clonal cultures indicates that cells of this parasite are diploid and suggests that sexual reproduction could be occurring in its life cycle. These results are preliminary due to the sample size managed and will need to be confirmed in further investigations. Also, most individual hosts from the Iberian Peninsula $(75 \%)$ showed different genotypes in at least 2 clonal cultures, suggesting that isolate cultures initiated from a single infected clam may comprise more than one strain of $P$. olseni. These observations are in accordance with those by Reece et al. (2001) in the congeneric species $P$. marinus and showed the utility of these microsatellites to detect multiple parasite infections in individual mollusks. All polymorphic loci showed strong and significant departures from Hardy-Weinberg expectations due to heterozygote deficit. Deviations may be the result of the Wahlund effect, which is likely due to the large geographic range of the sample, and/or of inbreeding. Deviations detected at all loci do not support an explanation based on null alleles. We also evaluated the crossamplification of these loci in 5 clonal cultures of $P$. mediterraneus deriving from infected European flat oyster Ostrea edulis from Maó (Menorca, Balearic Islands, Spain). Isolate cultures were established from oyster hearts, and clonal cultures were produced as described for $P$. olseni. The ranges of $\mathrm{MgCl}_{2}$ (1.5 to $2 \mathrm{mM})$ and temperature $\left(48\right.$ to $\left.60^{\circ} \mathrm{C}\right)$ were considered for PCR optimization. Eight out of the 12 loci tested were successfully amplified in $P$. mediterraneus, but only 2 showed size range differences with $P$. olseni, thus limiting their use as diagnostic interspecific markers (Table 2). The markers developed in the present work will be useful for analyzing in detail the population genetic structure of $P$. olseni. This knowledge is crucial for the efficient management of the parasitic disease.

Acknowledgements. This study was supported by the Ministerio de Ciencia e Innovación of the Spanish government, under the project AGL2006-11809. B.G.P. and R.V. were supported by an Isidro Parga Pondal research fellowship from Xunta de Galicia (Spain); E.A. was supported by a Ramón y Cajal contract of the Ministerio de Ciencia e Innovación of the Spanish Government. The authors thank José Antonio Álvarez-Dios for bioinformatic support and Lucía Insua, Susana Sánchez, María López, Andrea Ramilo, and Ricío Vicente for technical assistance. We are indebted to C. Dungan for supplying clonal cultures of Perkinsus olseni isolated from $R$. philippinarum and A. stutchburyi from Japan and New Zealand, respectively.

\section{LITERATURE CITED}

Ajzenberg D, Bañuls AL, Tibayrenc M, Darde ML (2002) Microsatellite analysis of Toxoplasma gondii shows considerable polymorphism structured into two main clonal groups. Int J Parasitol 32:27-38

Ascenso RMT, Leite RB, Afonso R, Cancela ML (2009) Expression pattern of Perkinsus olseni genes in response to bivalves with different susceptibility to perkinsosis. J Fish Dis 32:633-636

Asmundsson IM, Dubey JP, Rosenthal BM (2006) A genetically diverse but distinct North American population of Sarcocystis neurona includes an overrepresented clone described by 12 microsatellite alleles. Infect Genet Evol 6:352-360

Azevedo C (1989) Fine structure of Perkinsus atlanticus n. sp. (Apicomplexa, Perkinsea) parasite of the clam Ruditapes decussatus from Portugal. J Parasitol 75:627-635

Balmer O, Palma C, Macleod A, Caccone A (2006) Characterization of di-, tri- and tetranucleotide microsatellite markers with perfect repeats for Trypanosoma brucei and related species. Mol Ecol Notes 6:508-510

Belkhir K (2004) GENETIX v.4.05. Laboratoire genome, populations, interactions. CNRS UMR 5000, Université de Montpellier II, Montpellier, France. Available at www. genetix.univ-montp2.fr/genetix/genetix.htm.

Casas SM, La Peyre JF, Reece KS, Azevedo C, Villalba A (2002a) Continuous in vitro culture of the carpet shell clam Tapes decussatus protozoan parasite Perkinsus atlanticus. Dis Aquat Org 52:217-231

Casas SM, Villalba A, Reece KS (2002b) Study of the perkinsosis of the carpet shell clam Tapes decussatus in Galicia (NW Spain). I. Identification of the aetiological agent and in vitro modulation of zoosporulation by temperature and salinity. Dis Aquat Org 50:51-65

Feng XC, Rich SM, Akiyoshi D, Tumwine JK and others (2000) Extensive polymorphism in Cryptosporidium parvum identified by multilocus microsatellite analysis. Appl Environ Microbiol 66:3344-3349

Hine PM (2001) Problems of applying risk analysis to aquatic organisms. In: Rodgers CJ (ed) Risk analysis in aquatic animal health. Office Internationale des Epizooties (OIE), Paris, p 71-82 
Karunaweera ND, Ferreira MU, Hartl DL, Wirth DF (2007) Fourteen polymorphic microsatellite DNA markers for the human malaria parasite Plasmodium vivax. Mol Ecol Notes 7:172-175

Nei M (1987) Molecular evolution genetics. Columbia University Press, New York, NY

Pardo BG, Hermida M, Fernández C, Bouza C, Pérez M and others (2006) A set of highly polymorphic microsatellites useful for kinship and population analysis in turbot (Scophthalmus maximus L.). Aquacult Res 37:1578-1582

Pardo BG, Fernández C, Hermida M, Vázquez A and others (2007) Development and characterization of 248 novel microsatellite markers in turbot (Scophthalmus maximus). Genome 50:329-332

Park K, Choi KS, Choi JW (1999) Epizootiology of Perkinsus sp. found in the manila clam Ruditapes philippinarum in Komsoe Bay, Korea. J Korean Fish Soc 32:303-309

Reece KS, Bushek D, Hudson KL, Graves JE (2001) Genetic distribution of Perkinsus marinus genetic strains along the Atlantic and Gulf coasts of the USA. Mar Biol 139: 1047-1055

Rougeron V, De meeûs T, Hide M, Waleckx E and others (2010)

Editorial responsibility: Eugene Burreson,

Gloucester Point, Virginia, USA
A battery of 12 microsatellite markers for genetic analysis of the Leishmania (Viannia) guyanensis complex. Parasitology 137: 1879-1884

Santmartí MM, García Valero J, Montes J, Pech A, Durfort M (1995) Seguimiento del protozoo Perkinsus sp. en las poblaciones de Tapes decussatus y Tapes semidecussatus del delta del Ebro. In: Castelló F, Calderer (eds) Actas del $\mathrm{V}$ Congreso Nacional de Acuicultura. Universidad de Barcelona, Barcelona, p 260-265

Su X, Hayton K, Wellems TE (2007) Genetic linkage and association analyses for trait mapping in Plasmodium falciparum. Nat Rev Genet 8:497-506

Teles-Grilo ML, Duarte SM, Tato-Costa J, Gaspar-Maia A and others (2007) Molecular karyotype analysis of Perkinsus atlanticus (phylum Perkinsozoa) by pulsed field gel electrophoresis. Eur J Protistol 43:315-318

Villalba A, Reece KS, Ordás MC, Casas SM, Figueras A (2004) Perkinsosis in molluscs: a review. Aquat Living Resour 17:411-432

Zane L, Bargelloni L, Patarnello T (2002) Strategies for microsatellite isolation: a review. Mol Ecol 11:1-16

Submitted: September 13, 2010; Accepted: December 15, 2010 Proofs received from author(s): March 23, 2011 